\title{
PERBEDAAN KEANEKARAGAMAN JENIS IKAN BERDASARKAN MUSIM DI SUNGAI PENYERANG KECAMATAN PUDING BESAR KABUPATEN BANGKA
}

\section{DIFFERENCES IN THE DIVERSITY OF FISH SPECIES BASED ON THE SEASON IN THE PENYERANG RIVER WATER OF PUDING BESAR DISTRICT, BANGKA REGENCY}

\author{
Dewi Sari ${ }^{1}$, Eva Utami ${ }^{2}$, dan Indra Ambalika Syari ${ }^{2}$ \\ ${ }^{1,}$ Program Studi Manajemen Sumberdaya Perairan, FPPB-UBB, Balunijuk \\ ${ }^{2}$ Program Studi Ilmu Kelautan, FPPB-UBB, Balunijuk \\ Email korespondensi: dewi61529@gmail.com
}

Diterima Mei; disetujui September; tersedia secara online Oktober

\begin{abstract}
Penyerang River is one of the River found in the village Kayu Besi, Puding Besar Subdistrict, district of Bangka. Seasonal differences can also cause changes in environmental conditions in the River ecosystem so that a direct impact on the decline in species diversity of fish, and species composition. This study aims to analyze the influence of the season on the diversity of fish species found in the Penyerang River Waters. The study was carried out in JanuaryMarch 2018. The study took 6 observation stations 2 in the upstream, 2 in the middle and 2 in the downstream. The fishing tools used for sampling fish are dance nets, net gill and drag. Fish sampling is done in the morning until evening and from the afternoon until the morning. The results of caught fish are 470 individuals, there are 8 families, 11 genera, and 5 species. Fish diversity index at station $\mathrm{I}=1,461$, station $\mathrm{II}=1,543$, station $\mathrm{III}=1,674$, station $\mathrm{IV}=1,803$, station $\mathrm{V}=1,566$ and station $\mathrm{VI}=1,873$, included in the criteria classified as medium. Based on the analysis of the I One-Way Annova test for differences in seasons of the diversity of fish species, the $p_{\text {value }}>0.05$ is a 0.631 means that there is no difference.
\end{abstract}

Keyword: Musim, Indeks Keanekaragaman, Sungai Penyerang

\section{PENDAHULUAN}

Sungai Penyerang merupakan sungai yang berada di Desa Kayu Besi, Kecamatan Puding Besar, Kabupaten Bangka. Sungai Penyerang memiliki panjang sekitar $7.500 \mathrm{~m}$ dari hasil olahan data citra landsat $\mathrm{ETM}^{+}$ (Enhanced Thematic Mapper plus) tahun 2007. Nama sungai "Penyerang" berasal dari pernyataan warga yang melihat banyak anak sungai yang bercabang dan mengalir ke badan sungai utama. Berdasarkan keberadaan airnya Sungai Penyerang tergolong sungai Intermiten, yaitu sungai yang berair di musim hujan dan kering di musim kemarau. Sungai Penyerang melintasi dua desa di kecamatan ini yaitu Desa Kayu Besi dan Desa Puding Besar. Sungai Penyerang berhulu di Tenggara Desa Mangka dan berhilir di timur Desa Kayu Besi menuju sungai Kayu Besi. Di sebelah kanan sungai mulai dari hulu sampai hilir berbatasan dengan perkebunan sawit milik PT. Gunung Maras Lestari (GML) dengan luasan 23.976 ha, yang mulai beroperasi sejak tahun 1995 ini berbatasan dengan Sungai Penyerang mulai dari hulu sampai hilir. Di sekitar sungai terdapat aktivitas seperti perkebunan lada dan perkebunan karet sehingga dapat mempengaruhi keanekaragaman jenis ikan yang ada di Sungai Penyerang (BPS, 2009; Bakosultanal, 2007; Meina, 2010 dalam Gustomi, 2010).

Perubahan kedalaman air pada musim hujan dapat mempengaruhi kondisi kualitas air dan ritme kehidupan ikan, perubahan kedalaman air merupakan faktor utama yang menentukan struktur komunitas ikan. Perbedaan musim juga dapat menyebabkan perubahan kondisi lingkungan di ekosistem sungai sehingga berdampak langsung pada penurunan keanekaragaman jenis ikan dan komposisi jenis (Hartoto, 2003). Penelitian mengenai keanekaragaman ikan di Sungai Penyerang sudah pernah dilakukan pada musim kemarau yang tergolong sedang dengan nilai indeks keanekaragaman 0,958-1,801 (Gustomi, 2010). Adanya penelitian lanjutan selain bulan tersebut agar dapat mengetahui keanekaragaman jenis ikan di Sungai Penyerang sepanjang musim sehingga menjadi pertimbangan untuk melanjutkan penelitian di Sungai Penyerang. Selain itu untuk melihat perbandingan keanekaragaman jenis ikan di tahun 2010 dan 2018.

Penelitian ini bertujuan untuk menganalisis perbedaan keanekaragaman jenis ikan berdasarkan musim di Sungai Penyerang, Kecamatan Puding Besar, Kabupaten Bangka.

\section{METODE PENELITIAN}

Penelitian ini dilaksanakan pada bulan JanuariMaret 2018 di Sungai Penyerang Desa Kayu Besi, Kecamatan Puding Besar, Kabupaten Bangka. Identifikasi sampel ikan dilakukan di Laboratorium Perikanan, Fakultas Pertanian, Perikanan dan Biologi Universitas Bangka Belitung dan mengacu kepada 
Gustomi (2010). Peta lokasi penelitian dapat dilihat pada Gambar 1.

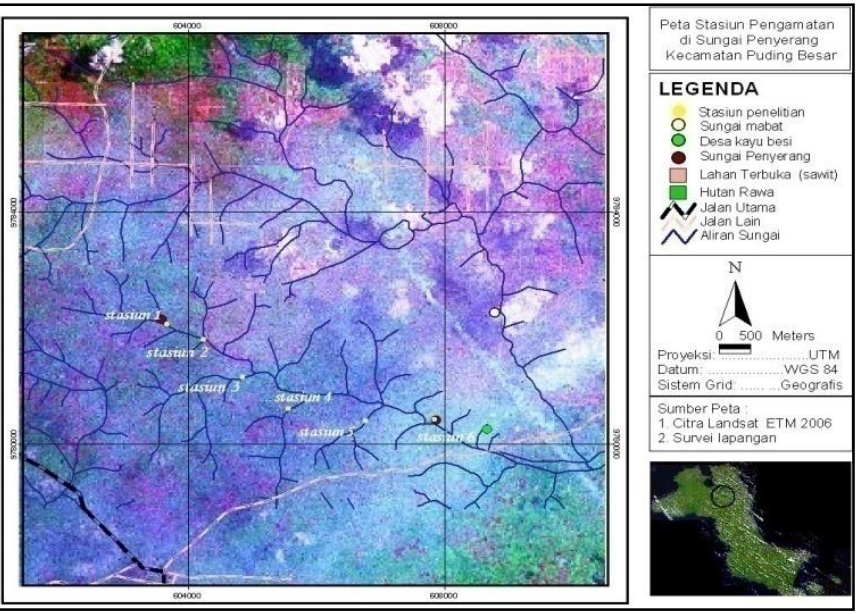

Gambar 1. Sungai Penyerang (Gustomi,2010)

Penentuan stasiun pengambilan contoh berdasarkan titik penelitian sebelumnya (Gustomi, 2010). Stasiun pengambilan contoh berjumlah 6 stasiun dengan tujuan untuk memenuhi keterwakilan sampel data. Titik

\begin{tabular}{clll}
\hline St. & \multicolumn{2}{c}{ Titik Koordinat } & \multicolumn{1}{c}{ Keterangan } \\
\hline I & $01^{\circ} 58^{\prime} 16,7^{\prime \prime}$ LS & $105^{\circ} 55^{\prime} 57,6^{\prime \prime} \mathrm{BT}$ & Lahan terbuka hutan ilalang \\
II & $01^{\circ} 58^{\prime} 25,2^{\prime \prime}$ LS & $105^{\circ} 56^{\prime} 16,1^{\prime \prime} \mathrm{BT}$ & Pertemuan anak sungai \\
III & $01^{\circ} 58^{\prime} 46,3^{\prime \prime}$ LS & $105^{\circ} 56^{\prime} 35,9^{\prime \prime} \mathrm{BT}$ & Anak sungai dan perkebunaan sawit GML \\
IV & $01^{\circ} 59^{\prime} 04,1^{\prime \prime}$ LS & $105^{\circ} 56^{\prime} 59,0^{\prime \prime} \mathrm{BT}$ & Hutan rawa \\
V & $01^{\circ} 59^{\prime} 11,1^{\prime \prime}$ LS & $105^{\circ} 57^{\prime} 38,2^{\prime \prime} \mathrm{BT}$ & Anak sungai dan perkebunan sawit GML \\
VI & $01^{\circ} 59^{\prime} 09,8^{\prime \prime} \mathrm{LS}$ & $105^{\circ} 58^{\prime} 12,7^{\prime \prime} \mathrm{BT}$ & Lubuk-lubuk sungai \\
\hline
\end{tabular}

Keterangan : St. = stasiun

pengambilan sampel disajikan pada Tabel 1. sebagai berikut :

Tabel 1. Titik Pengambilan Sampel terdapat 2 substasiun sehingga terdapat 6 stasiun pengambilan sampel. Adapun alat dan bahan yang digunakan dalam penelitian ini dapat dilihat pada Tabel 2 yaitu :

Tabel 2. Peralatan yang digunakan dalam penelitian

\begin{tabular}{|c|c|c|c|c|}
\hline No & \multicolumn{2}{|l|}{ Nama } & \multicolumn{2}{|l|}{ Kegunaan } \\
\hline 1 & \multicolumn{2}{|c|}{ Jaring Tuguk } & \multicolumn{2}{|l|}{ Untuk Menangkap Ikan } \\
\hline 2 & \multicolumn{2}{|c|}{ Serok } & \multicolumn{2}{|c|}{ Alat Penunjang penangkapan ikan } \\
\hline 3 & \multicolumn{2}{|c|}{ Roll Meter } & \multicolumn{2}{|c|}{ Mengukur luasan areal perairan } \\
\hline 4 & \multicolumn{2}{|c|}{ Plastik sampel dan ember } & \multicolumn{2}{|c|}{ Wadah Sampel } \\
\hline 5 & \multicolumn{2}{|c|}{ Kertas label } & \multicolumn{2}{|c|}{ Sebagai tanda pada setiap sampel } \\
\hline 6 & \multicolumn{2}{|c|}{ GPS } & \multicolumn{2}{|c|}{ Menentukan titik lokasi sampling } \\
\hline 7 & \multicolumn{2}{|c|}{ Kamera } & \multicolumn{2}{|c|}{ Mengambil gambar penelitian } \\
\hline 8 & \multicolumn{2}{|c|}{ Alat Tulis } & \multicolumn{2}{|l|}{ Mencatat jumlah sampel } \\
\hline 9 & \multicolumn{2}{|c|}{ Sterofoam } & \multicolumn{2}{|l|}{ Alas pengukuran dan foto ikan } \\
\hline 10 & \multicolumn{2}{|c|}{ Formalin } & \multicolumn{2}{|c|}{ Untuk mengawetkan sampel ikan } \\
\hline 11 & \multicolumn{2}{|c|}{ Alkohol } & \multicolumn{2}{|c|}{ Untuk menyimpan sampel ikan } \\
\hline 12 & \multicolumn{2}{|c|}{ Buku Identifikasi Ikan } & \multicolumn{2}{|c|}{ Pedoman identifikasi jenis ikan } \\
\hline & Parameter & Nama Alat & Kegunaan & Satuan \\
\hline & \multirow[t]{4}{*}{ Fisika } & Bola Arus dan Stopwatch & Mengukur kecepatan arus & $\mathrm{m} / \mathrm{s}$ \\
\hline & & Termometer & Mengukur suhu & ${ }^{0} \mathrm{C}$ \\
\hline & & Secchi disk & Mengukur kecerahan & $\mathrm{cm}$ \\
\hline & & Tiang Skala & Mengukur kedalaman & M \\
\hline & \multirow[t]{3}{*}{ Kimia } & pH Meter & Mengukur $\mathrm{pH}$ & - \\
\hline & & Peralatan Titrasi & Mengukur DO & $\mathrm{Mg} / \mathrm{l}$ \\
\hline & & Spektrofotometer & Mengukur Fosfat dan Nitrat & $\mathrm{ml}$ \\
\hline
\end{tabular}

Pengambilan sampel ikan dilakukan dengan alat tangkap yang terdiri dari jaring tarik dengan ukuran panjang $5 \mathrm{~m}$, lebar $2 \mathrm{~m}$ dengan mesh size $0,5 \mathrm{~cm}$ yang dioperasikan pada siang hari dengan cara memasukkan jaring ke dalam perairan, pada kedua ujung sisi jaring ditarik dengan bantuan kayu atau bambu berlawanan arus sejauh $50 \mathrm{~m}$ dengan 3 kali ulangan. Jaring insang (gillnet) dengan ukuran panjang jaring $10 \mathrm{~m}$, lebar 1,5 $\mathrm{m}$, dengan mesh size $1,5 \mathrm{~cm}$ dan $3 \mathrm{~cm}$ dioperasikan pada pagi hari hingga sore hari dengan cara membentang jaring menghalang arah arus dan dilakukan pada sore

hari dan diangkat pagi hari, dan serok sebagai alat tangkap penunjang. Sampel ikan yang diperoleh di lapangan dibawa ke Laboratorium Perikanan Fakultas Pertanian Perikanan dan Biologi Universitas Bangka Belitung untuk diawetkan dan diidentifikasi dengan mengacu pada Kottelat et al. (1993). Untuk membandingkan komposisi jenis ikan di Sungai Penyerang mengacu kepada penelitian gustomi, 2010).

Pengukuran parameter fisika (Suhu, Kecerahan, kedalaman dan kecepatan arus) dan kimia ( $\mathrm{pH}$, Oksigen 
Terlarut, Total Fosfat dan Nitrogen Total) adalah sebagai berikut:

Alat yang digunakan untuk mengukur arus adalah bola arus dan stopwatch. Bola yang telah diberi tali dengan panjang tertentu dihanyutkan sampai stopwatch dihidupkan. Setelah panjang tali menegang dan bola juga berhenti, stopwatch dimatikan, kecepatan arus dihitung dengan cara membagi panjang tali (m) dengan lama waktu yang diukur (s) (Effendi, 2003).

Suhu

Suhu perairan diukur dengan menggunakan thermometer. Thermometer dimasukan ke dalam air selama kurang lebih dua menit, kemudian pembacaan nilai suhu dilakukan pada saat thermometer masih berada di dalam air agar suhu yang terukur tidak dipengaruhi oleh suhu udara.

Kecerahan

Kecerahan air diukur dengan menggunkan secchi disk dengan cara secchi disk dicelupkan perlahan-lahan ke dalam air, kemudian diamati saat secchi disk mulai tidak terlihat warna hitam putih. Langkah selanjutnya diukur kedalamannya (m) setelah itu secchi disk diangkat lagi secara perlahan-lahan dan diamati saat secchi disk mulai terlihat warna hitam putihnya, setelah itu diukur lagi kedalamannya (n). Selain itu diukur pula kedalaman perairan (Z). Perhitungan kecerahan adalah sebagai berikut (Effendi, 2003) :

$$
\mathrm{C}=0,5 \frac{(m+n)}{z} \times 100 \%
$$

Perhitungan kelimpahan relatif setiap jenis ikan dilakukan dengan perhitungan presentase jumlah (Brower et al., 1990). Rumus perhitungan terdapat di bawah ini:

$$
\mathrm{Kr}=\frac{n \tilde{i}}{N} \mathrm{x} 100 \%
$$

\begin{tabular}{|c|c|c|c|c|c|c|c|}
\hline \multirow{2}{*}{ No } & \multirow{2}{*}{ Spesies } & \multicolumn{6}{|c|}{ Stasiun Penelitian } \\
\hline & & I & II & III & IV & $\mathbf{V}$ & VI \\
\hline 1 & Betta anabatoides & - & 1.11 & 0.96 & 3.23 & - & 0.437 \\
\hline 2 & Channa lucius & - & - & - & - & - & 0.437 \\
\hline 3 & Channa striata & - & - & - & - & - & 0.873 \\
\hline 4 & Cyclocheilichthys armatus & - & - & - & - & 6.45 & 0.873 \\
\hline 5 & Homaloptera sp & - & - & - & - & 2.15 & - \\
\hline 6 & Osteochilus spilurus & - & 1.111 & 7.69 & 3.23 & 12.9 & 10.04 \\
\hline 7 & Nandus nebulosus & 8 & - & - & 1.61 & 1.08 & - \\
\hline 8 & Kryptopterus sp & - & - & - & - & - & 0.873 \\
\hline 9 & Luciocephalus pulcher & - & - & 1.92 & - & - & 0.873 \\
\hline 10 & Mystus sp & - & - & - & - & 1.08 & - \\
\hline 11 & Nemacheilus selangoricus & 4 & 4.444 & - & 14.5 & 5.38 & 11.35 \\
\hline 12 & $\begin{array}{l}\text { Neohomaloptera } \\
\text { johorensis }\end{array}$ & - & - & 0.96 & 3.23 & - & 0.437 \\
\hline 13 & Puntius binotatus & 24 & 14.44 & 0.96 & 12.9 & - & -3.057 \\
\hline 14 & Puntius johorensis & - & - & 0.96 & - & - & - \\
\hline 15 & Rasbora bankanensis & - & 55.56 & 52.9 & 56.5 & 21.5 & 10.04 \\
\hline 16 & Rasbora cephalotaenia & - & 7.778 & 6.73 & - & 41.9 & 20.52 \\
\hline 17 & Rasbora sp & - & 1.111 & 23.1 & - & - & 38.86 \\
\hline \multirow[t]{2}{*}{18} & Dermogenys sumatrana & 64 & 14.44 & 3.85 & 4.48 & 7.53 & 1.31 \\
\hline & Total & 100 & 100 & 100 & 100 & 100 & 100 \\
\hline
\end{tabular}

Tabel 3. Kelimpahan relatif (Kr) ikan tiap stasiun di Sungai Penyerang pada Musim Kemarau (Gustomi, 2010)

Sumber: (Gustomi,2010)

Frekuensi Keterdapatan

Frekuensi keterdapatan dapat menunjukan luasnya penyebaran local jenis tertentu. Hal ini dilihat dari frekuensi (\%) ikan yang ditangkap dengan rumus :

$$
\mathrm{Fi}=\frac{\mathrm{ti}}{T} \times 100 \%
$$

\section{Kecepatan Arus}

Kedalaman

Pengukuran kedalaman perairan dilakukan menggunakan tiang skala. Tiang skala dimasukkan ke dalam perairan saat permukaan air tenang, nilai kedalaman dapat dilihat pada tiang skala.

Potensial Hidrogen $(\mathrm{pH})$

Nilai $\mathrm{pH}$ diukur dengan menggunakan $\mathrm{pH}$ paper dengan cara memasukkan $\mathrm{pH}$ paper ke dalam perairan selama kurang lebih dua menit, angkat dan ditempelkan pada kotak indikator dan dibaca yang tertera pada kotak indikator.

Dissolved Oxygen ( DO)

Pengukuran oksigen terlarut secara elektrik dengan menggunakan DO meter. Penentuan konsentrasi oksigen terlarut dengan cara ini dilakukan dengan memasukan elektroda ke dalam sampel air selanjutnya nilai konsentrasi oksigen terlarut dapat dibaca pada display (Effendi, 2003).

Total Phospat $\left(\mathrm{PO}_{4}\right)$ dan Nitrogen Total (N-Total)

Pengukuran total Phospat dan Nitrogen total dilakukan di Laboratorium Dinas Lingkungan Hidup Provinsi Kepulauan Bangka Belitung.

Analisis Data

Komposisi Jenis

Jumlah jenis ikan secara keseluruhan yang diperoleh dari hasil tangkapan atau sampling selama penelitian.

Kelimpahan Relatif

$$
\begin{aligned}
& \text { Keterangan : } \\
& \mathrm{Kr}=\text { kelimpahan relatif } \\
& \mathrm{Ni}=\text { jumlah individu spesies ke-i } \\
& \mathrm{N}=\text { jumlah total individu semua spesies }
\end{aligned}
$$


ti $=$ jumlah stasiun dimana spesies ke-i yang tertangkap (\%)

$\mathrm{T}=$ jumlah semua stasiun

Indeks keanekaragaman

Untuk menentukan keanekaragaman ikan digunakan indeks Shannon-Wiener Fachrul, 2006 dengan rumus sebagai berikut :

$$
\mathrm{H}^{\prime}=\Sigma\left(\frac{n i}{N}\right) \ln \frac{n i}{N}
$$

$$
\begin{aligned}
& \mathrm{H}^{\prime}=\text { Indeks Diversitas Shannon-Wiener } \\
& \mathrm{Ni}=\text { jumlah individu spesies ke-i } \\
& \mathrm{N}=\text { jumlah individu semua spesies }
\end{aligned}
$$

Penentuan Kriteria :

$$
\begin{array}{ll}
\mathrm{H}^{\prime}<1 & =\text { keanekaragaman rendah } \\
1<\mathrm{H}^{\prime}<3 & =\text { keanekaragaman sedang } \\
\mathrm{H}^{\prime}>3 & =\text { keanekaragaman tinggi }
\end{array}
$$

Indeks Keseragaman

Diversitas maksimum $\left(\mathrm{H}_{\text {maks }}\right.$ terjadi bila kelimpahan semua spesies disemua stasiun merata atau apabila $\mathrm{H}^{\prime}=$ $\mathrm{H}_{\text {maks }}=\log _{2}$. Rasio keanekaragaman yang terukur dengan keanekaragaman maksimum dapat dijadikan keseragaman $(\mathrm{E})$ :

\section{S}

$$
\mathrm{E}=\frac{H^{s}}{\text { Hmaks }} \quad \mathrm{H}_{\max }=\log _{2}
$$

Keterangan :

$$
\begin{array}{ll}
\mathrm{E} & =\text { indeks keseragaman } \\
\mathrm{H} & =\text { indeks keanekaragaman Shannon-Wiener } \\
\mathrm{H}_{\text {maks }} & =\text { keanekaragaman Maksimum } \\
\mathrm{S} & =\text { jumlah spesies }
\end{array}
$$

Nilai indeks keseragaman berkisar antara 0-1. Indeks yang mendekati 0 menunjukan adanya jumlah individu yang tekonsentrasi pada satu atau beberapa jenis. Hal ini dapat diartikan ada beberapa jenis biota yang memiliki jumlah jenis individu relatif banyak, sementara beberapa jenis lainnya memiliki jumlah individu yang relatif sedikit. Nilai indeks keseragaman yang mendekati 1 menunjukkan bahwa jumlah individu di setiap spesies adalah sama atau hampir sama.

Indeks Dominansi

Untuk mengetahui ada tidaknya dominansi, digunakan indeks dominansi Simpson (Legendre \& Legendre, 1983 dalam Setyobudiandi et al. 2009) :

$$
\mathrm{C}=\Sigma\left(\frac{n i}{N}\right)^{2}
$$

Keterangan :

$\mathrm{C}=$ Indeks dominansi Simpson

$\mathrm{Ni}=$ jumlah individu spesies ke-i

$\mathrm{N}=$ jumlah individu semua spesies

Nilai indeks dominansi berkisar anatar 0-1 ; indeks 1 menunjukkan dominansi oleh satu jenis spesies sangat tinggi (hanya terdapat satu jenis pada satu stasiun) sedangkan indeks 0 menunjukkan bahwa di antara jenisjenis yang ditemukan tidak ada yang mendominansi.

Uji Annova Satu Arah (One Way Annova)

One way annova jenis uji statistika parametrik yang bertujuan untuk mengetahui apakah terdapat perbedaan raata-rata antara lebih dari dua sampel. Dalam penelitian ini one way annova bertujuan untuk mengetahui ada tidaknya perbedaan pada musim hujan dan musim kemarau di Sungai Penyerang. Data komposisi jenis ikan yang didapatkan pada musim kemarau dapat dilihat dari penelitian (Gustom, 2010). ANNOVA satu arah yang perlu dilihat adalah $\mathrm{P}_{\text {value }}$, jika nilai $\mathrm{P}_{\text {value }}>0,05$ maka keputusan terima $\mathrm{H}_{0}$ artinya tidak ada perbedan musim. Selain itu dapat dilihat dengan membandingkan nilai $\mathrm{F}_{\text {hitung }}(\mathrm{F})$ dengan $\mathrm{F}_{\text {tabel }}\left(\mathrm{F}_{\text {crit }}\right)$. Jika Terlihat bahwa $\mathrm{F}_{\text {hitung }}$ lebih kecil dari $\mathrm{F}_{\text {tabel }}$ adalah $(4,32)$ maka keputusan sama yaitu terima $\mathrm{H}_{0}$ sehingga dapat disimpulkan tidak terdapat perbedaan musim.

Keterangan :

$\mathrm{H}_{0}$ diterima jika signifikasi $\mathrm{P}_{\text {value }}>0,05$

\begin{tabular}{|c|c|c|c|c|c|}
\hline No & Famili & Genus & Spesies & $\begin{array}{l}\text { Nama } \\
\text { Lokal }\end{array}$ & Status \\
\hline 1 & Osphronemidae & Betta & Betta anabatoides & Tepala & $\mathrm{TL}$ \\
\hline 2 & Cyprinidae & Cyclocheilichthys & $\begin{array}{l}\text { Cyclocheilichthys } \\
\text { armatus }\end{array}$ & Keperas & TL \\
\hline 3 & Cyprinidae & Osteochilus & $\begin{array}{l}\text { Osteochilus } \\
\text { spilurus }\end{array}$ & Kepaet & TL \\
\hline 4 & Nandidae & Nandus & Nandus nebulosus & Ketiber & TL \\
\hline 5 & Siluridae & Kryptopterus & Kryptopterus sp & Tepurong & TL \\
\hline 6 & Luciocephalidae & Luciocephalus & $\begin{array}{l}\text { Luciocephalus } \\
\text { pulcher }\end{array}$ & Templusok & TL \\
\hline 7 & Cyprinidae & Puntius & Puntius binotatus & Tanah & TL \\
\hline 8 & Cyprinidae & Rasbora & $\begin{array}{l}\text { Rasbora } \\
\text { bankanensis }\end{array}$ & Kemuntis & TL \\
\hline 9 & Cyprinidae & Rasbora & $\begin{array}{l}\text { Rasbora } \\
\text { chepalotaenia }\end{array}$ & $\begin{array}{l}\text { Seluang } \\
\text { hitam }\end{array}$ & TL \\
\hline 10 & Hemiramphidae & Dermogenys & $\begin{array}{l}\text { Dermogenys } \\
\text { sumatrana }\end{array}$ & $\begin{array}{l}\text { Julung- } \\
\text { julung }\end{array}$ & $\mathrm{TL}$ \\
\hline 11 & Siluridae & Kryptopterus & Kryptopterus lais & Lais & TL \\
\hline 12 & Cyprinidae & Puntius & Puntius lineatus & Kemuring & TL \\
\hline 13 & Cyprinidae & Rabora & Rasbora & Seburai & $\mathrm{TL}$ \\
\hline 14 & Singnathidae & Syngnathoides & $\begin{array}{l}\text { sumatrana } \\
\text { Syngnathoides } \\
\text { biaculeatus }\end{array}$ & $\begin{array}{l}\text { Tangkur } \\
\text { Buaya }\end{array}$ & $\mathrm{TL}$ \\
\hline
\end{tabular}

$\mathrm{H}_{0}$ ditolak jika signifikasi $\mathrm{P}_{\text {value }}<0,05$

\section{HASIL DAN PEMBAHASAN}

Komunitas Sumberdaya Hayati Ikan Pada Musim Penghujan dan Data Komposisi Jenis Ikan Pada Musim Kemarau dan Musim Penghujan di Sungai Penyerang

Hasil Identifikasi dan analisis jenis-jenis ikan yang diperoleh dari Sungai penyerang Kabupaten Bangka dan status jenis ikan tersebut mengacu kepada Kepmen.KLHK.P.106 2018 dapat dilihat pada Tabel 4, 5 dan 6. sebagai berikut:

Tabel 4. Klasifikasi jenis-jenis ikan di Sungai Penyerang Musim Penghujan 


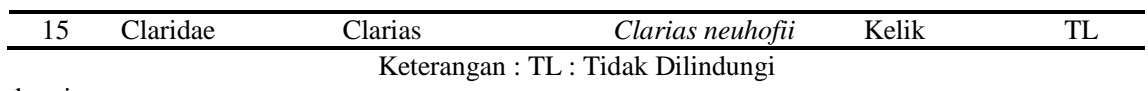

$\mathrm{L}$ : Dilindungi

Ikan yang diperoleh pada musim hujan yaitu 15 spesies. Secara keseluruhan ikan yang diperoleh terbagi atas 8 famili. Berdasarkan jenis ikan yang ditemukan di perairan Sungai Penyerang terlihat bahwa jenis ikan terbanyak berasal dari famili Cyprinidae. Menurut Kottelat et al. (1993) famili Cyprinidae merupakan suku air tawar yang sangat besar dan terdapat hampir di setiap Tabel 5. Data komposisi ikan yang didapatkan pada musim kemarau dan musim penghujan di Sungai Penyerang

\begin{tabular}{|c|c|c|c|c|}
\hline \multirow[b]{2}{*}{ No } & \multirow[b]{2}{*}{ Famili } & \multirow[b]{2}{*}{ Spesies } & \multicolumn{2}{|c|}{ Jumlah } \\
\hline & & & $\begin{array}{c}\text { Musim } \\
\text { Kemarau }\end{array}$ & $\begin{array}{c}\text { Musim } \\
\text { Penghujan }\end{array}$ \\
\hline 1 & Osphronemidae & Betta anabatoides & 5 & 2 \\
\hline 2 & Channidae & Channa lucius & 1 & 0 \\
\hline 3 & & Channa striata & 1 & 0 \\
\hline 4 & Cyprinidae & Cyclocheilichthys armats & 8 & 11 \\
\hline 5 & & Osteochilus spirulus & 46 & 47 \\
\hline 6 & & Puntius binotatus & 35 & 88 \\
\hline 7 & & Puntius johorensis & 1 & 0 \\
\hline 8 & & Rasbora bankanensis & 172 & 178 \\
\hline 9 & & Rasbora cephalotania & 142 & 49 \\
\hline 10 & & Rasbora sp. & 72 & 0 \\
\hline 11 & & Puntius lineatus & 0 & 14 \\
\hline 12 & & Rasbora sumatrana & 0 & 22 \\
\hline 13 & Balitoridae & Homaloptera sp. & 2 & 0 \\
\hline 14 & & Nemacheilus selangoricus & 45 & 0 \\
\hline 15 & & $\begin{array}{l}\text { Neohomaloptera } \\
\text { johorensis }\end{array}$ & 21 & 0 \\
\hline 16 & Nandidae & Nandus nebulosus & 4 & 8 \\
\hline 17 & Siluridae & Kryptopterus sp. & 2 & 1 \\
\hline 18 & & Kryptopterus lais & 0 & 12 \\
\hline 19 & Luciocephalidae & Luciocephalus pulcher & 0 & 3 \\
\hline 20 & Bagridae & Mystus sp. & 1 & 0 \\
\hline 21 & Hemiramphidae & Dermogenys sumatrana & 46 & 23 \\
\hline 22 & Singnathidae & Syngnathoides biaculeatus & 0 & 1 \\
\hline 23 & Claridae & Clarias neuhofii & 0 & 2 \\
\hline & Total & & 604 & 461 \\
\hline
\end{tabular}

Jumlah ikan yang ditemukan di sungai penyerang terdapat 23 spesies yang dimana pada musim kemarau berjumlah 604 sedangkan pada musim penghujan 461 . Famili yang didapatkan di Sungai Penyerang berjumlah 11 famili, yang paling banyak yaitu spesies Cyprinidae yang berjumlah 9 spesies ditemukan di Sungai Penyerang. Ikan dari famili siluridae umumnya ditemukan pada kondisi perairan dengan $\mathrm{pH}$ rendah, Siluridae kebanyakan terdiri dari spesies ikan yang tahan terhadap kondisi deoksigenasi dan diistilahkan sebutan "blackfish". Ikan ini sebagian besar waktu hidupnya dihabiskan di perairan keruh. Perairan keruh dicirikan oleh warna air yang coklat tua sampai kehitaman. Pada musim penghujan air yang terdapat di Sungai Penyerang akan berubah. Substrat akan teraduk oleh arus air yang berubah dan volume air akan bertambah. Air tersebut menjadi coklat yang menyebabkan ikan ini ditemukan pada musim penghujan. Spesies ikan kelik dapat bertahan hidup di perairan yang airnya sedikit oksigen (Yustina. 2001). Bentuk adaftasi morfologi spesies ini terdapat pada sungut yang bisa mendeteksi makanan di perairan yang keruh dan spesies dari famili Cyprinidae ini memiliki kemampuan beradaftasi pada kondisi perairan yang cenderung bersifat asam (Effendi. 2003). Famili Cyprinidae juga menyukai suhu $22-27{ }^{\circ} \mathrm{C}$ (Kottelat et al., 1993). Variansi nilai pengukuran suhu di setiap stasiun selama penelitian berkisar antara $25,8{ }^{\circ} \mathrm{C}$ - tempat di dunia kecuali Australia, Madagaskar, Selandia Baru, dan Amerika Serikat. Musim kemarau terdapat 9 famili dan 18 spesies terlihat bahwa jenis ikan terbanyak berasal dari famili Cyprinidae. Semua spesis ikan yang didapat pada musim kemarau dan musim penghujan memiliki status tidak dilindungi. 
ditemukan karena ditemukan ular yang tertangkap pada alat tangkapnya..Pada musi penghujan tidak ditemukan karena lama pengangkatan hasil tangkapannya dikarenakan hujan deras, sehingga ular akan memakan hasil tangkapan berupa ikan tersebut serta populasi nya sudah berkurang. Pada musim penghujan ditemukan ikan Kryptopterus lais merupakan ikan yang memiliki bentuk badan yang sedikit pipih dan panjang. Ikan yang termasuk dalam famili siluridae ini memiliki ukuran sekitar 4 Inci hingga $10 \mathrm{~cm}$, namun ada juga yang memiliki ukuran lebih panjang (Yuyun., 2013). Ikan yang memiliki kumis panjang ini dapat hidup dalam perairan dengan suhu $24-27^{\circ} \mathrm{C}$ yaitu dalam suhu yang hangat dan tidak terlalu dingin. Ikan lais ini merupakan pemakan segalanya atau dapat mengkonsumsi tumbuhan ataupun daging. Spesies Syngnathoides biaculeatus merupakan spesies langka karena hewan ini ada di laut dan di sungai air tawar. Makanan ikan ini berupa udang kecil didasar perairan karena pada musim penghujan volume air akan bertambah sehingga asupan makan di perairan sangat banyak, sehingga menjadi sumber makanan bagi ikan, hal ini lah kenpa pada musim kemarau tidak ditemukan. Spesies Clarias teijsmanni ditemukan pada musim penghujan karena hidupnya di perairan hita atau coklat tua, pada musim penguhjan subtratnya akan teraduk karena arus air yang berubah dan volume air yang bertambah, ikan ini juga dapat hidup di perairan yang sedikit oksigen dan pencemaran bahan organik, ikan ini juga hidup dimalam hari. Spesies Luciocephalus pulcher memiliki wilayah penyebaran yang sempit denganfrekuensi keterdapatan rata-rata $16,67 \%$ karena jenis ikan ini merupakan ikan yang menyukai perairan $\mathrm{pH}$ 6-7,5, sedangkan $\mathrm{pH}$ musim penghujan yaitu 6 (Yuyun. 2013). Spesies Homaloptera sp. Nemacheilus selangoricus, Neohomaloptera johorensis merupakan famili Balitoridae. Famili ini hidup di perairan yang jernih

Tabel 6. Komposisi jenis ikan tiap stasiun di Sungai Penyerang

\begin{tabular}{|c|c|c|c|c|c|c|c|c|}
\hline \multirow{2}{*}{ No } & \multirow{2}{*}{ Spesies } & \multirow{2}{*}{ Famili } & \multicolumn{6}{|c|}{ Stasiun } \\
\hline & & & $\mathbf{I}$ & II & III & IV & $\mathbf{V}$ & VI \\
\hline \multirow{2}{*}{$\begin{array}{l}1 \\
2\end{array}$} & Betta anabatoides & Osphronemidae & - & - & - & - & 1 & 1 \\
\hline & $\begin{array}{l}\text { Cyclocheilichthys } \\
\text { armatus }\end{array}$ & Cyprinidae & 3 & 3 & 5 & - & - & - \\
\hline 3 & Osteochilus spilurus & Cyprinidae & - & 8 & 7 & 10 & 18 & 4 \\
\hline 4 & Nandus nebulosus & Nandidae & 2 & - & 2 & - & - & 4 \\
\hline 5 & Kryptopterus sp & Siluridae & 1 & - & - & - & - & - \\
\hline 6 & Luciocephalus pulcher & Luciocephalidae & - & - & 3 & - & - & - \\
\hline 7 & Puntius binotatus & Cyprinidae & 17 & 7 & 11 & 12 & 20 & 21 \\
\hline 8 & Rasbora bankanensis & Cyprinidae & 43 & 48 & 31 & 22 & 14 & 20 \\
\hline \multirow{2}{*}{$\begin{array}{l}9 \\
10\end{array}$} & Rasbora chepalotaenia & Cyprinidae & 5 & 11 & 10 & - & 19 & 4 \\
\hline & $\begin{array}{l}\text { Dermogenys } \\
\text { sumatrana }\end{array}$ & Hemiramphidae & 5 & 6 & 2 & 2 & 2 & 6 \\
\hline 11 & Kryptopterus lais & Kryptopterus & - & - & - & 12 & - & - \\
\hline 12 & Puntius lineatus & Puntius & - & - & - & 11 & 1 & 2 \\
\hline \multirow{2}{*}{$\begin{array}{l}13 \\
14\end{array}$} & Rasbora sumatrana & Rabora & 6 & 5 & - & 8 & - & 3 \\
\hline & $\begin{array}{l}\text { Syngnathoides } \\
\text { biaculeatus }\end{array}$ & Syngnathoides & - & - & - & - & - & 1 \\
\hline 15 & Clarias neuhofii & Clarias & - & 2 & - & - & - & - \\
\hline & Jumlah & & 82 & 90 & 71 & 77 & 75 & 75 \\
\hline
\end{tabular}

Secara keseluruhan ikan yang tertangkap di Sungai Penyerang terdiri dari 15 jenis atau 15 spesies. Komposisi ikan-ikan hasil tangkapan bervariasi pada setiap stasiun pengamatan, seperti ikan Kemuntis, Tanah dan Julung-julung merupakan jenis ikan yang terdapat di setiap stasiun. Namun komposisi ikan kemuntis lebih banyak dibandingkan kedua jenis ikan terdapat pada stasiun II yaitu 48 individu. Kemuntis merupakan jenis dengan sebaran pada perairan tawar Sumatera dan Kalimantan (Gustomi. 2010). Bisa jadi kata "bankanensis" pada jenis ini yang menjelaskan spesies dari ikan tersebut berawal dari banyaknya spesies ini ditemukan di perairan tawar, kemuntis ditemukan di seluruh bagian Sungai Penyerang (Gustomi.2010). Habitat perairan Sungai penyerang sesuai dengan kemuntis karena ikan ini ditemukan di musim kemarau dan musim penghujan, berdasarkan analisis One Way Annova berati tidak berbedanyata. Menurut Gustomi (2016) jenis ikan ini menjelaskan berawal dari banyaknya spesies ini yang ditemukan perairan Pulau Bangka. Menurut Gustomi (2016) banyak anggota dari Cyprinidae seperti misalnya spesies kemuntis menggunakan sungutnya untuk mendeteksi makanan di dalam perairan yang keruh dan berarus deras. Spesies ini paling banyak ditemukan di perairan Sungai Penyerang, karena pada saat pengambilan sampel ikan terjadi turun hujan yang mengakibatkan perairan keruh. Sifat makanan ikan julung-julung dan kemuntis termasuk ikan herbivora, makanannya berupa partikel-partikel kecil yang besarnya disesuaikan dengan bentuk mulutnya yang kecil. Berdasarkan hasil pengamatan dipenuhi vegetasi dan akar-akar pohon disekitaran tepi sungai sehingga digunakan ikan kemuntis sebagai tempat berlindung. Kelompok Siluridae kebanyakan terdiri dari spesies ikan yang tahan terhadap kondisi deoksigenasi dan diistilahkan sebutan "blackfish". Ikan ini sebagian besar waktu hidupnya dihabiskan di perairan hitam, perairan hitam dicirikan oleh warna air yang coklat tua sampai kehitaman, pada musim penghujan air yang terdapat di Sungai Penyerang substratnya akan teraduk karena arus air berubah dan volume air juga akan bertambah, sehingga air tersebut menjadi coklat, hal ini menyebabkan ikan ini ditemukan pada musim penghujan. Spesies Kelik ikan yang tahan hidup di perairan yang airnya sedikit oksigen ikan ini juga tahan terhadap pencemaran bahan organik sehingga ikan ini mampu hidup di air yang kotor. Ikan ini aktif pada malam hari. 
Tabel 7. Kelimpahan relatif (Kr) ikan tiap stasiun di Sungai Penyerang

\begin{tabular}{|c|c|c|c|c|c|c|c|}
\hline \multirow{2}{*}{ No } & \multirow{2}{*}{ Spesies } & \multicolumn{6}{|c|}{ Stasiun } \\
\hline & & I & II & III & IV & $\mathbf{V}$ & VI \\
\hline 1 & Betta anabatoides & - & - & - & - & 1.333 & 1.33 \\
\hline 2 & $\begin{array}{l}\text { Cyclocheilichthys } \\
\text { armatus }\end{array}$ & 3.659 & 3.333 & 7.042 & - & - & - \\
\hline 3 & Osteochilus spilurus & - & 8.889 & 9.859 & 12.99 & 24 & 24 \\
\hline 4 & Nandus nebulosus & 2.439 & - & 2.817 & - & - & 5.333 \\
\hline 5 & Kryptopterus sp. & 1.219 & - & - & - & - & - \\
\hline 6 & Luciochepalus pulcher & - & - & 4.225 & - & - & - \\
\hline 7 & Puntius binotatus & 20,73 & 7,78 & 15,492 & 14.285 & 1.333 & 2.667 \\
\hline 8 & Rasbora bankanensis* & 52.439 & 53.333 & 43.662 & 28.571 & 18.667 & 20 \\
\hline 9 & $\begin{array}{l}\text { Rasbora } \\
\text { chepalotaenia* }\end{array}$ & 6.098 & 12.222 & 14.084 & - & 25.333 & 5.194 \\
\hline 10 & Dermogenys sumatrana & 6.098 & 6.667 & 2.817 & 2.597 & 2.667 & 8 \\
\hline 11 & Kryptopteruslais & - & - & - & 15.584 & - & - \\
\hline 12 & Puntius lineatus & - & - & - & 14.285 & 1.333 & 2.667 \\
\hline 13 & Rabora sumatrana & 7.317 & 5.556 & - & 10.389 & - & 4 \\
\hline 14 & $\begin{array}{l}\text { Syngnathoides } \\
\text { biaculeatus }\end{array}$ & - & - & - & - & - & 1.333 \\
\hline 15 & Clarias neuhofii & - & 2.222 & - & - & - & - \\
\hline
\end{tabular}

Kelimpahan relatif ikan tertinggi antar semua stasiun pengamatan terdapat pada stasiun II yaitu spesies kemuntis dengan nilai 53,333\%. Stasiun I, III, IV, kelimpahan relatif tertinggi ditempati oleh Rasbora bankanensis (Kemuntis) dengan nilai persentase kelimpahan pada stasiun I sebanyak $52,439 \%$, stasiun III $43,662 \%$, stasiun IV sebanyak $28,571 \%$, stasiun V dan VI kelimpahan tertinggi ditempati oleh Puntius binotatus, dengan nilai pada stasiun $\mathrm{V}$ sebanyak $26,667 \%$ dan stasiun VI sebanyak 28\%. Hal ini dikarenakan vegetasi yang terdapat di sekitar sungai masih lebat yang merupakan habitat yang disukai ikan untuk mencari makanan dan berlindung. Selain itu pada stasiun I sampai IV juga merupakan kelimpahan rektif tinggi. Kemuntis merupakan jenis ikan dengan sebaran pada perairan air tawar Sumatra dan Kalimantan. Bisa jadi "bankanensis" pada jenis ini yang menjelaskan spesies dari ikan tersebut berawal dari banyaknya spesies ini yang ditemukan di perairan tawar Pulau Bangka. Begitu juga di perairan spesies kemuntis merupakan jenis yang terbanyak ditemukan di Sungai Penyerang tersebut. Rasbora bankanensis ditemukan hampir di semua stasiun. Pada musim kemarau kemuntis hanya ditemukan di 5 stasiun yaitu staisun II-VI sedangkan pada stasiun I tidak ditemukan. Berdasarkan pengamatan parameter fisika perairan yaitu vegetasi diskitar sungai pada staisun II, sedangkan kelimpahan relatif paling tinggi yaitu Kemuntis, sedangkan pada musim kemarau kelimpahan paling tinggi adalah ikan Julung-julung. Pada stasiun V Rasbora chepalotaenia merupakan jenis dengan kelimpahan relatif tertinggi. Kelimpahan relatif pada stasiun VI adalah jenis Osteochilus spilurus paling tinggi. Menurut Kottelet et al. (1993) famili Cyprinidae menyukai suhu perairan yaitu $22-27^{\circ} \mathrm{C}$, berdasarkan hasil pengukuran fisika kimia perairan yaitu nilai suhu perairan Sungi Penyerang memiliki nilai suhu perairan $25,8-26,3^{\circ} \mathrm{C}$, hal ini menyebabkan spesies ikan ini melimpah di perairan Sungai Penyerang. Kelimpahan ikan terendah terdapat pada spesies Kryptopterus sp.

Tabel 8. Frekuensi keterdapatan (\%) jenis ikan di Sungai Penyerang

\begin{tabular}{cccc}
\hline No & Spesies & Jumlah & Fi $(\%)$ \\
\hline 1 & Betta anabatoides & 2 & 33,33 \\
2 & Cyclocheilichthys armatus & 3 & 50 \\
3 & Osteochilus spilurus & 5 & 83,33 \\
4 & Nandus nebulosus & 3 & 50 \\
5 & Kryptopterus sp & 1 & 16,67 \\
6 & Luciocephalus pulcher & 1 & 16.67 \\
7 & Puntius binotatus & 6 & 100 \\
8 & Rasbora bankanensis & 6 & 100 \\
9 & Rasbora chepalotaenia & 5 & 83.33 \\
10 & Dermogenys sumatrana & 6 & 100 \\
11 & Kryptopterus lais & 1 & 16,67 \\
12 & Puntius lineatus & 1 & 50 \\
13 & Rasbora sumatrana & 4 & 66,67 \\
14 & Syngnathoides biaculeatus & 1 & 16,67 \\
15 & Clarias neuhofii & 1 & 16,67 \\
\hline
\end{tabular}

Frekuensi keterdapatan ikan tertinggi antara stasiun yaitu terdapat 3 spesies yaitu Rasbora bankanensis, Puntius binotatatus dan Dermagenys sumatrana dengan nilainya persentase $100 \%$. Hal tersebut dikarenakan ketiga spesies tersebut ditemukan pada setiap stasiun penelitian. Frekuensi keterdapatan jenis ikan dari semua stasiun yang tertinggi yaitu Rasbora bankanensis (kemuntis), Puntius binotatus (tanah), dan Dermogenys 
sumatrana (julung-julung) dengan persentase keterdapatan $100 \%$. Apabila dilihat dari pola sebaran ketiga jenis ikan tersebut tidak hanya pada musim kemarau tetapi musim hujan juga terdapat sebarannya. Famili Cryprinidae memang telah dikenal sebagai penghuni utama yang paling besar populasinya untuk beberapa sungai di Sumatera (Fithra, 2010). Frekuensi keterdapatan terendah yaitu terdapat 5 spesies yaitu Clarias neuhofii (kelik), Kryptopterus sp. (Tepurong), Luciocephalus pulcher (Templusok), Kryptopterus lais
(Lais), dan Syngnathoides biaculeatus (Tangkur Buaya) dengan frekuensi keterdapatan 16,67\%. Spesies Syngnathoides biaculeatus (Tangkur Buaya) merupakan spesies langka karena hewan ini ada yang hidup di laut, sungai air tawar dan danau, ikan ini disebut juga bajulan. Makanan ikan ini berupa udang-udang kecil di dasar sungai atau dasar laut karena pada musim penghujan volume air akan bertambah sehingga asupan makan di perairan sangat banyak, sehingga menjadi sumber makanan bagi ikan.

Tabel 9. Nilai Indeks Keanekaragaman, Keseragaman dan Dominansi

\begin{tabular}{cccc}
\hline \multirow{2}{*}{ Stasiun } & \multicolumn{3}{c}{ Indeks } \\
\cline { 2 - 4 } & $\mathbf{H}^{\prime}$ & $\mathbf{E}$ & $\mathbf{C}$ \\
\hline I & 1,461 & 0,332 & 0,702 \\
II & 1,543 & 0,321 & 0,742 \\
III & 1,674 & 0,251 & 0,805 \\
IV & 1,803 & 0,177 & 0,926 \\
V & 1,566 & 0,228 & 0,805 \\
VI & 1,873 & 0,19 & 0,813 \\
\hline Rata-rata \pm SB & $\mathbf{1 , 6 5 3} \pm \mathbf{0 , 1 5 9}$ & $\mathbf{0 , 2 4 9} \pm \mathbf{0 , 0 6 5}$ & $\mathbf{0 , 7 9 8} \pm \mathbf{0 , 0 7 6}$ \\
\hline
\end{tabular}

Nilai indeks keanekaragaman di perairan Sungai Penyerang tergolong sedang dengan nilai berkisar antara 1,461-1,873, indeks keanekaragaman jenis ikan paling tinggi adalah pada stasiun VI sebesar 1,873. Berdasarkan indeks keanekaragaman tersebut. Menurut Basmi (1999) dalam Fachrul (2008) nilai $1<\mathrm{H}^{\prime}<3$ berarti perairan memiliki stabilitas komunitas biota sedang. Nilai indeks keanekaragaman tersebut tergolong sedang. Nilai indeks keanekaragaman ikan pada musim penghujan lebih tinggi dibandingkan dengan keanekaragaman jenis ikan pada musim kemarau. Kondisi demikian menurut Odum (1998) menunjukkan kestabilan komunitas biota atau tekanan ekologi sedang. Selain itu faktor arus dan hujan juga dapat mempengaruhinya, karena pada saat pengambilan sampel ikan terjadi hujan otomatis menyebabkan terjadi perubahan arus perairan. Arus merupakan faktor yang memiliki peranan penting bagi perairan sungai. Berdasarkan klasifikasi Mason (1981) dalam Agustina (2013). Stasiun I, II, III, V, dan VI termasuk Sungai dengan arus lambat $(12,05-23,81 \mathrm{~m} / \mathrm{s})$ sedangkan stasiun IV berarus sedang $(46,51 \mathrm{~m} / \mathrm{s})$. Arus lambat sampai sedang memungkinkan banyaknya partikel-partikel makanan yang bersumber dari hulu maupun jatuhan serangga dan daun dari pepohonan yang tertahan lama di badan perairan yang dibawa arus pada saat terjadi hujan tersebut, merupakan sumber makanan bagi biota salah satunya ikan. Selain itu menurut Barus (2000) dalam agustina (2013), sungai yang berarus lambat ini merupakan habitat yang sangat ideal bagi organisme air yang tidak mempunyai adaptasi khusus melawan arus air yang deras. Kecepatan arus yang lambat sampai sedang pada Sungai Penyerang juga dipengaruhi oleh alur sungai yang umumnya berliku-liku pada semua stasiun pengamatan sehingga memungkinkan kecepatan arus perairan tertahan. Suhu di perairan Sungai Penyerang berkisar antara $25,8-26,4^{\circ} \mathrm{C}$. Menurut Effendi (2003) suhu perairan dengan kisaran optimum $20-30^{\circ} \mathrm{C}$, sangat baik bagi pertumbuhan fitoplankton di perairan. Menurut Sutisna dan Sutarmantob (1995) dalam Jukri et al. (2013) kisaran suhu yang baik bagi pertumbuhan ikan adalah antara $25-35^{\circ} \mathrm{C}$. Menurut Purwanto et al. (2014) suatu perairan yang belum tercemar akan menunjukkan jumlah individu yang seimbang dari semua spesies yang ada. Derajat keasaman (pH) di perairan Sungai Penyerang ini masih dapat ditoleransi oleh populasi ikan perairan tersebut walaupun umumnya ikan menyukai $\mathrm{pH}$ dengan kisaran optimal 6,5-8,5 (Barus, 2000).

Ikan mempunyai tolerir terdapat $\mathrm{pH}$ antara 4-11. Kecenderungan kondisi asam di perairan Sungai Penyerang ini kemungkinan disebabkan banyaknya serasah terdekomposisi di sepanjang aliran sungai yang sebagian besar adalah hutan. Kandungan oksigen terlarut perairan Sungai Penyerang cenderung layak bagi kehidupan ikan yaitu 6,3-8,2 mg/L (Haryono, 2001 dalam Gustomi, 2010). Menurut Haryono dalam Agustina (2013) kadar oksigen terlarut yang baik bagi ikan minimal $3 \mathrm{mg} / \mathrm{l}$ dan menurut Effendi (2003) sebaiknya tidak kurang dari $8 \mathrm{mg} / \mathrm{L}$. Berdasarkan pengamatan parameter kimia diperoleh nilai nitrogen total berkisar antara $0,263-0,651 \mathrm{mg} / \mathrm{L}$ sedangkan nilai fosfat rata-rata $<0,0313$. Pada musim penghujan parameter kimia diperoleh nilai nitrogen total terbesar pada stasiun $60 \mathrm{mg} / \mathrm{l}$. Nilai indeks keanekaragaman tertinggi pada musim hujan yaitu pada stasiun VI dengan nilai 1,873 tergolong sedang, sedangkan pada musim kemarau nilai indeks keanekaragaman yaitu 1,801 pada stasiun VI yang tergolong sedang, pada kedua musim tersebut indeks keanekaragamannya tergolong sedang, hanya saja perubahan nilai indeks keanekaragamannya, karena nilai indeks keanekaragaman pada musim hujan lebih besar dibandingkan musim kemarau. Nilai rata-rata keanekaragaman adalah 1,653 sedangkan untuk nilai simpangan bakunya 0,159 . Nilai indeks keseragaman (E) dari semua stasiun pengamatan berkisar antara 0,702-0,926. Nilai tersebut menunjukkan bahwa keseragaman jenis di Sungai Penyerang tergolong tinggi. Menurut Odum (1998) dalam Agustina (2013) nilai keseragaman $\mathrm{E} \leq 0,4$ berarti keseragaman populasi 
rendah; $0,4 \leq \mathrm{C} \leq 0,6$ yang berarti keseragaman populasi sedang; $\mathrm{E} \geq 0,6$ berarti keseragaman populasi tinggi. Berdasarkan kriteria tersebut Sungai Penyerang memiliki keseragaman populasi tinggi, artinya populasi jenis ikan menyebar merata pada semua stasiun. Kecenderungan menyebarnya ikan pada semua stasiun dapat diperkirakan kondisi habitat perairan yang memiliki kondisi lingkungan perairan hampir seragam, yang masih layak untuk kehidupan ikan. Nilai rata-rata keseragaman yang didapatkan adalah 0,249 dan nilai simpangan baku yaitu 0,065 . Nilai indeks dominansi berkisar antara 0,702-0,926, dimana dominansi paling tinggi adalah pada stasiun IV sebesar 0,926. Menurut Odum (1998) nilai demikian berarti tidak terdapat spesies yang mendominansi jenis lainnya atau jumlah jenis setiap ikan merata dan ekosistem perairan dikatakan stabil. Nilai Indeks Dominansi berkisar antara 0,702-0,926. Menurut Odum (1998) dalam Agustina (2013) nilai demikian berarti tidak terdapat spesies yang

Tabel 10. Daftar ikan pada musim kemarau dan musim penghujan serta Indeks Keanekaragaman dan Dominansi mendominansi spesies lainnya atau jumlah jenis setiap ikan merata dan ekosistem perairan sungai dapat dikatakan stabil atau tidak terdapat spesies yang mendominansi spesies lainnya, karena tingginya nilai indeks keanekaragaman di Sungai Penyerang. Nilai dominansi berbanding terbalik dengan nilai keanekaragaman, apabila nilai keanekaragaman tinggi maka nilai dominansinya rendah, sebaliknya apabila nilai keanekaragamannya rendah maka nilai dominansinya tinggi. Indek dominansi mempunyai nilai rata-rata 0,798 dan nilai simpangan baku adalah 0,076, apabila nilainya sama dengan nol, maka semua nilai yang ada ialah sama, sementara nilai simpangan baku yang lebih besar atau kecil menandakan bahwa titik data individu tersebut jauh dari nilai rata-rata, jadi nilai simpangan baku untuk indeks keanekaragaman, indeks keseragaman dan indeks dominansi ialah nilai nya jauh dari nilai rata-rata kerena nilainya lebih besar dari 0 .

\begin{tabular}{|c|c|c|c|}
\hline No & Spesies & $\begin{array}{c}\text { Kemarau } \\
\text { (Gustomi, 2010) }\end{array}$ & $\begin{array}{c}\text { Penghujan } \\
\text { (2018) }\end{array}$ \\
\hline 1 & Betta anabatoides & $\checkmark$ & $\checkmark$ \\
\hline 2 & Cyclocheilichthys armatus & $\checkmark$ & $\checkmark$ \\
\hline 3 & Osteochilus spilurus & $\checkmark$ & $\checkmark$ \\
\hline 4 & Nandus nebulosus & $\checkmark$ & $\checkmark$ \\
\hline 5 & Kryptopterus sp & $\checkmark$ & $\checkmark$ \\
\hline 6 & Luciocephalus pulcher & $\checkmark$ & $\checkmark$ \\
\hline 7 & Puntius binotatus & $\checkmark$ & $\checkmark$ \\
\hline 8 & Rasbora bankanensis & $\checkmark$ & $\checkmark$ \\
\hline 9 & Rasbora chepalotaenia & $\checkmark$ & $\checkmark$ \\
\hline 10 & Dermogenys sumatrana & $\checkmark$ & $\checkmark$ \\
\hline 11 & Kryptopterus lais & - & $\checkmark$ \\
\hline 12 & Puntius lineatus & - & $\checkmark$ \\
\hline 13 & Rasbora sumatrana & - & $\checkmark$ \\
\hline 14 & Syngnathoides biaculeatus & - & $\checkmark$ \\
\hline 15 & Clarias neuhofii & - & $\checkmark$ \\
\hline 16 & Channa lucius & $\checkmark$ & - \\
\hline 17 & Channa striata & $\checkmark$ & - \\
\hline 18 & Homaloptera sp. & $\checkmark$ & - \\
\hline 19 & Mystus sp. & $\checkmark$ & - \\
\hline 20 & Nemacheilus selangoricus & $\checkmark$ & - \\
\hline 21 & $\begin{array}{l}\text { Neohomaloptera } \\
\text { johorensis }\end{array}$ & $\checkmark$ & - \\
\hline 22 & Puntius johorensis & $\checkmark$ & - \\
\hline 23 & Rasbora $s p$ & $\checkmark$ & - \\
\hline H' & & 0,958-1,801 & $1,461-1,873$ \\
\hline $\mathbf{C}$ & & $0,227-0,475$ & $0,702-0,926$ \\
\hline & Total Spesies & 18 & 15 \\
\hline
\end{tabular}

Tabel 11. Nilai parameter fisika dan kimia di Sungai Penyerang

\begin{tabular}{ccccccc}
\hline \multirow{2}{*}{ Parameter } & I & II & III & IV & V & VI \\
\cline { 2 - 6 } & \multicolumn{7}{c}{ *Fisika } & & & & \\
\hline Kecepatan arus (m/s) & 23,81 & 12,05 & 22,47 & 46,51 & 15,11 & 16,34 \\
Suhu $\left({ }^{\circ} \mathrm{C}\right)$ & 26 & 25,8 & 26 & 26,3 & 26,4 & 26,3 \\
Kecerahan (\%) & 100 & 100 & 100 & 52,82 & 45,14 & 43,91 \\
Kedalaman (cm) & 90 & 87 & 170 & 115 & 175 & 156 \\
\hline *Kimia & \multicolumn{7}{c}{6} & 6 & 6 & 6 \\
\hline pH & 6 & 6 & 6 & 6,8 & 6,3 & 6,9 \\
DO (mg/L) & 7,8 & 8,2 & 7,4 & $<, 0,031$ & $<0,031$ & $<0,031$ \\
Total Fosfat & $<0,031$ & $<0,031$ & $<0,031$ & $<0,031$ \\
(mg/L) & 3 & 3 & 3 & 3 & 3 & 3 \\
N-Total (mg/L) & 0,402 & 0,647 & 0,263 & 0,265 & 0,518 & 0,651 \\
\hline
\end{tabular}

Tabel 12. Hasil uji One-Way Annova perbedaan musim terhadap keanekaragaman

Komposisi Spesies $\quad P$-Value $\quad$ Keterangan




\begin{tabular}{ccc}
\hline Komposisi Spesies & $\boldsymbol{P}$-Value & Keterangan \\
\hline Musim Kemarau dan Musim Hujan & 0,631 & Tidak berbeda nyata \\
\hline
\end{tabular}

Analisis ragam hasil perhitungan Uji One-Way Annova di dapatkan nilai $\mathrm{F}_{\text {hitung }}(0,631)$ dan $\mathrm{F}_{\text {tabel }}(4,32)$ membuktikan tidak ada perbedaan di setiap musim karena $\mathrm{H}_{0}$ diterima, karena nilai $\left(\mathrm{F}_{\text {hitung }}<\mathrm{Ftabel}\right)$, sehingga tidak ada perbedaan terhadap musim penghujan dan musim kemarau. Jenis ikan yang hampir sama ditemukan di musim kemarau dan musim hujan membuat nilai uji annova tidak jauh berbeda dan juga penelitian dilakukan di satu aliran sungai sehingga spesies ikan yang ditemukan tidak berbeda hanya berbeda dalam jumlah hasil tangkapan saja, dan jumlah familinya karena penelitian dilakukan di satu aliran sungai sehingga spesies ikan yang ditemukan tidak berbeda dan hanya berbeda serta nilai keanekaragaman, keseragaman dan dominansinya tidak jauh berbeda. Ekosistem yang baik mempunyai ciri-ciri keanekaragaman jenis yang tinggi dan penyebaran jenis individu yang hampir merata disetiap perairan. Kondisi perairan masih cukup baik. Ekosistem yang baik mempunyai ciri-ciri keanekaragaman jenis ikan yang tinggi dan penyebaran jenis individu yang hampir merata di setiap perairan. Tidak adanya perbedaan antar musim kemarau dan musim hujan karena tingkat aktivitas yang terdapat di sekitaran sungai masih rendah. Hasil di atas juga dapat dikaitkan dengan pengukuran parameter-parameetr lingkungan yang dilakukan pada saat penelitian. Hasil pengukuran nitrogen yang mana pada musim kemarau nilai nitrogen total lebih besar dibandingkan dengan nilai nitrogen total pada musim hujan adalah $0,263-0,651 \mathrm{mg} / \mathrm{L}$. Nilai total fosfat pada musim hujan yaitu $<0,0313 \mathrm{mg} / \mathrm{L}$. Pada pengukuran parameter tersebut pada saat hujan, karena nilai total fosfat yang didapatkan berada di bawah nilai kriteria kesuburan mesotrofik, sehingga nilai yang muncul adalah nilai MDL yang bisa dipertanggung jawabkan. Hasil pengukuran suhu perairan berkisar yaitu 25,8 26,40C, suhu pada musim hujan berbeda dengan suhu pada musim kemarau. Hasil pengukuran $\mathrm{pH}$ perairan di semua stasiun bernilai 6 yang berarti asam. Kondisi perairan yang asam merupakan ciri dari sebagian besar perairan wilayah Pulau Bangka (Muslih, 2014). Hasil pengukuran kedalaman perairan di setiap stasiun terjadi peningkatan, karena pada saat hujan deras, volume air akan bertambah sehingga membuat kedalaman perairan akan bertambah juga, sehingga kedalaman pada musim hujan lebih besar dibandingkan dengan kedalaman pada musim kemarau. Arus sangat penting kaitannya dengan kehidupan hewan atau organisme karena arus dapat menyebabkan perubahan suhu. Pengukuran kecepatan arus disemua stasiun berkisar antara 12,05-46,51 m/s. Sungai yang berarus lambat merupakan habitat yang angat ideal bagi organisme air yang tidak mempunyai adaptasi khusus melawan arus air yang deras (Barus, 2000).

Variasi nilai untuk pengukuran kecerahan berkisar antara 43,91-100\%. Kecerahan memiliki peran yang tinggi dalam proses fotosintesis oleh organisme fitoplankton pada lingkungan perairan. Pengukuran kadar DO tersebut dapat mempengaruhi keberadaan ikan maupun organisme lain yang ada di dalamnya. DO merupakan jumlah gas $\mathrm{O}^{2}$ yang diikat oleh molekul air. Sumber utama DO dalam perairan yaitu dari proses fotosintess tumbuhan dan penyerapan atau pengikat secara langsung oksigen dari udara melalui kontak antara permukaan air dengan udara. Apabila kecerahan air keruh maka proses fotosintesisnya terganggu. Parameter-parameter lingkungan yang diukur didapatkan hasil yang tidak jauh berbeda, hal ini menunjukkan bahwa kondisi perairan dari Sungai Penyerang masih cukup baik untuk kehidupan ikan. Nilai dari perhitungan uji One-Way Annova membuktikan bahwa $F_{\text {hitung }}$ tidak berada didaerah penerimaan $\left(\mathrm{F}_{\text {hitung }}>\mathrm{F}_{\text {tabel }}\right)$ maka Ho ditolak, sehingga bisa disimpulkan setiap musim tidak adanya perbedaan yang nyata antara kedua musim tersebut.

\section{KESIMPULAN DAN SARAN}

\section{Kesimpulan}

Berdasarkan hasil penelitian dapat disimpulkan bahwa indeks keanekaragaman jenis ikan pada musim penghujan berkisar antara 1,461-1,873 sedangkan pada musim kemarau berkisar antara 0,958-1,801. Pada musim penghujan jumlah spesiesnya ikan yang ditemukan sebanyak 15 spesies sedangkan pada musim kemarau berjumlah 18 spesies. Berdasarkan analissi uji One Way Annova terhadap keanekaragaman jenis ikan pada musim penghujan dan musim kemarau tidak berbeda nyata $(\mathrm{p}>0,005+0,631)$.

Saran

Adapun saran yang dapat peneliti sampaikan yaitu: Adanya penelitian lanjutan menggunakan alat tangkap tugu dan bubu pada musim kemarau dan hujan di Sungai Penyerang. Perlu adanya penelitian lanjutan biologi reproduksi ikan di Sungai Penyerang.

\section{DAFTAR PUSTAKA}

Adis MA, Setyawati TR dan Yanti AH. 2014. Keragaman Jenis Ikan Arus Deras di Aliran Riam Banagar Kabupaten Landak. Jurnal Protobiont. 3 (2): 209-217.

Bakosurtanal, 2007. Pengelolaan Citra Digital Landsat ETM tahun 2006. Badan Koordinasi Survei dan Pemetaan Nasional. Bogor.

Barus. T.A. 2000. Pengantar Limnologi. Universitas Sriwijaya. Palembang.

Brower, J. E., J. H. Zar, dan C. N. Von Ende. 1990. Fielid and Laboratory Methods for General Ecology. Wm.C.Brown Publishers, Boulevard USA.

BPS Kabupaten Bangka. 2009. Bangka dalam Angka. BPS Kabupaten Bangka: Sungailiat.

Daryanto, 2004. Masalah Pencemaran. Tarsito:Bandung. Effendi, H, 2003. Telaah Kualitas Air. Kanisius: Yogyakarta.

Fachrul, M. F. 2006. Metode Sampling Bioekologi. PT. Bumi Aksara: Jakarata.

Fithra.2010. keanekaragaman Ikan Sungai kampar Inventarisasi dari Sungai Kampar kanan. Jurnal Ilmu Lingkungan. 2 (4): 1-9

Gustomi A, Eva U. Prihatin I.W. 2010. Keanekaragaman Ikan Penyerang Kecamatan Puding 
Besar Kabupaten Bangka. (Skripsi) Fakultas Pertanian Perikanan dan Biologi Universitas Bangka Belitung.

Gustomi A, Eva U. Prihatin I.W. 2016. Biodiversity of fish in Penyerang River at District of Puding Besar, Bangka Regency. Journal of Aquatropica Asia.Vol.3/No.1/ Tahun 2016.

Hartoto, D. I. 2003. Relationship of water lever to water quality in an oxbow lake of Central Kalimantan. Proceedings of the International Symposium on Tropical Peatlands. Bogor 22-23 November 1999.

Jukri M, Emiyar dan Kamri S. 2013. Keanekaragaman Jenis Ikan di Sungai Lamunde Kecamatan Watubangga Kabupaten Kolaka Provinsi Sulawesi Tenggara. Jurnal Mina Laut Indonesia. 1 (1); 23-37.

Kottelat, M., A.J.Whitten., S.R. Kartikasari., and S Wirjoatmodjo. 1993. Freshwater Fishes of Western Indonesia nd Sulawesi- Ikan Air tawar Indonesia Bagian Barat dan Sulawesi. (edisi Dwi Bahasa). Periplus Editions LTD., Hongkong.

Muslih, K. 2013. Pengaruh Penambangan Timah Terhadap Keanekaragaman Ikan Sungai Dan Kearifan Lokal Masyarakat Di Kabupaten Bangka [Tesis]. Institut Pertanian Bogor. Bogor

Odum, E,P. 1998. Dasar-dasar Ekologi [edisi 3]. Translation Copyright Mada Univercity Press. Jogjakarta.

Peraturan Menteri Lingkungan Hidup dan Kehutanan No P.106/MENLHK/SETJEN/KUM.1/12/2018.

Salmin .2005. Oksigen Terlarut (DO) dan Kebutuhan Oksigen Biologi (BOD) Sebagai Salah Satu Indikator Untuk Menentukan Kualitas Perairan. Jurnal Osean 30 (3) : 21-26.

Samuel, Susilo. A. 2008. Zonasi, Karakteristik FisikaKimia Air dan Jenis-jenis Ikan Yang Tertangkap di sungai Musi, Sumatra Selatan. Jurnal ilmu-ilmu Perairan dan Perikanan Indonesia 15 (1): 41-48.

Sari, P, I. 2017.Analisis Kualitas Air Muara Sungai Kurau Kabupaten Bangka Tengah Ditinjau Dari Indeks Saprobitas Plankton.[Skripsi].Fakultas Pertanian, Perikanan dan Biologi, Program Studi Manajemen Sumberdaya Perairan. Universitas Bangka Belitung. Bangka Belitung.

Subagyo, Pangestu. 2017. Statistika Terapan. BPFE. Yogyakarta.

Setyobudiandi et al. 2009. Sampling dan Analisis Data Perikanan dan Kelautan Terapan Metode Pengambilan Contoh di Wilayah Pesisir dan Laut. Fakultas Perikanan dan Ilmu Kelauatan IPB.

Sulistiyanto B., Soedharma D., Rahardjo F M., dan Sumardjo. 2007. Pengaruh Musim Terhadap Komposisi Jenis dan kemelimpahan Ikan di Rawa Lebak, Sungai Rungan, Palangkaraya, Kalimantan Tengah. Jurnal Biodiversitas. 4 (8); 270-273.

Yustina. 2001. Keanekaragaman Jenis Ikan di Sepanjang Peraiaran Sungai Rangau Riau Sumatra. Natur Indonesia 4 (1); 1-14.

Yuyun. 2013. Keanekaragaman Jenis Ikan di Sungai Upang, Kabupaten Bangka [Skripsi]. Fakultas Pertanian, Perikanan dan Biologi. Universitas Bangka Belitung. 